\title{
An art that obscures: Baderoon regarding Muslims
}

\author{
[ B O O K REVIEW]
}

Baderoon, Gabeba (2015) Regarding Muslims: From slavery to post-apartheid. Johannesburg: Wits University Press (2014). ISBN 978-1-86814-769-4 pbk. Pages xix + 207

"Praise be to God for making us forget". These words, uttered by a White Helmets volunteer in Syria, is echoed in Gabeba Baderoon densely-layered Regarding Muslims in two ways. The shame of sexual violence and miscegenation associated with slavery at the Cape has led - and here Baderoon quotes Zoë Wicomb - to a "total erasure of slavery from folk memory" ( $p$ 88). But in a less salutary way, this forgetfulness is also characteristic of those who were the major beneficiaries of this institution. Colonists wished to forget slavery, and their representation of Cape Muslims - "Malays" - played a critical role in this forgetting. This is one of the main arguments that emerge from Baderoon's book.

Muslims had already arrived in the Cape in the 1650s and the majority of them formed a prominent part of the colony's slave population. The institution of slavery, of course, was central to the Cape polity and economy until its abolition in 1834. Consequently, Islam was integral to the matrix that made South Africa. Yet Islam in this country, in its imbrication with slavery, is not usually seen in this way and Baderoon seeks to explore why this is the case.

One reason is the tendency to consider the period of slavery as somewhat apart from the country's later history. A larger part of the answer lies in how Malays were depicted in colonial representation. The Malay was an
Auwais Rafudeen

Department of Religious

Studies and Arabic

UNISA

Pretoria 
exotic figure, quaint and colourful, who formed a picturesque, non-threatening backdrop to the Cape landscape. In the paintings and imagination of the period, he or she was a liminal and docile figure, who functioned to "translate slavery into the unremarkable and unremarked" ( $p 41)$. Baderoon provides a particularly stunning example of how this picturesque sensibility rendered the memory of slavery. Signal Hill, the site of a number of colonial-era landscapes, was also the location of the Muslim slave graveyard, the Tana Baru: "the urbane and aesthetically pleasing city represented in colonial-era paintings was therefore literally founded on slave bodies and their labour, but the picturesque landscape rendered the violence of slavery invisible." ( $\mathrm{p} 2$ ) In rendering Cape slavery as unremarkable and invisible, the picturesque sensibility also served to de-historicise the slaves and their descendants. They were not of interest in themselves but functioned "solely to add depth to white subjectivity" ( $\mathrm{p} 21$ ).

But Muslims and slaves were not only gazed upon, but they could gaze back and this caused a certain amount of consternation among colonists. Historically they may have been seen as docile on the whole but there was also the fear that they could run amok. This historical fear re-emerged in a markedly different form with the rise of Pagad in the 1990s. Similarly, Malay cooks were celebrated for their skill but there was also a wariness of their domestic secrets, potions and poisons and, more generally, their alternative epistemology. In addition, the Hajj pilgrimages helped centre Muslims around different temporalities and geographies than that to which they were subject by colonialism. They, in a word, had mechanisms and techniques by which to resist the picturesque mode. And it is anti-picturesqueness which defines the writing of a number of post-Apartheid South African authors of Muslim background - authors who show the many complex dimensions of Muslim identity. These authors have cut through Islamic and South African exceptionalism, as well as the binary of docility and menace. Baderoon writes that in their works "Muslims are no longer rendered invisible through an oscillation between picturesque and menacing but are subject to quotidian social and political process, creating a critical and comparative perspective that integrates Islam into ordinary considerations of history, politics, satire and feminism." ( $p$ 159)

Baderoon's writing is highly evocative and excels in combining penetrating historical scholarship with the psychological insights of literature. Yet, to my mind, this fine piece of post-colonial interpretation contains a considerable omission. Baderoon pays no attention to the scholarship produced by Cape Muslims (including slavescholars) during the $18^{\text {th }}, 19^{\text {th }}$ and early $20^{\text {th }}$ centuries in particular. The books, chains of scholarly transmission, and systems of learning that characterized this period, and whose languages were Arabic, Melayu and Arabic-Afrikaans, communicated the guiding norms of the community. They were integral to a tradition that embodied and articulated a way of living reality - one that still largely guides the norms of Cape 
Muslims today. It is a tradition undergirded by a specific system of metaphysics and manifested in a specific relation to law, ethics and aesthetics - a system that shaped the rhythms of everyday living. I suggest that it was this system that formed the primary site of "resistance" to the colonial worldview and the set of practices that it typically inaugurated. Put another way, slaves had their own parallel institutions of learning, guidance and practice that were not contained by the representational discourse of colonialism. And while the study of representation is important precisely for the reasons Baderoon has shown - as the undermining of a colonial conceit - the alternative metaphysics of the Muslim slaves was oriented towards a rather different temporal and spatial framework. And so, this metaphysics, as shown in the work of someone like Tuan Guru (died 1807), managed, evaluated and contained the colonial reality in its turn. In a sense this metaphysics transcends the work of the writers described by Baderoon, who for all their complexity, are still inscribed in the dominant temporal-spatial framework inaugurated by the Enlightenment.

There is a revealing comment by Baderoon when discussing her interviews with older Muslim pilgrims who had performed the Hajj. She notes that she was an "unusual listener, drawn by details that seemed to the hajjis to be of passing interest only" ( $p$ 77). But I wonder what results would have been yielded if she directed her considerable talents to the types of questions they did expect. What detailed forms of life and embodied practices would she have been able to uncover? What kinds of understanding would have been developed regarding the metaphysics that undergirds them? Of course, this was not her brief but such an exploration, I suggest, is not only a necessary complement to representational discourse but indeed rightly provincializes the latter. The erasure of slavery from folk-memory was not only a product of trauma, but also a consequence of hope. 